\title{
Effect of the conversion of mangroves into shrimp farms on carbon stock in the sediment along the southern Red Sea coast, Saudi Arabia
}

Ebrahem M. Eid ${ }^{1,2}$, Muhammad Arshad ${ }^{3}$, Kamal H. Shaltout ${ }^{4}$, Mohamed A. El-Sheikh ${ }^{5,6}$, Ahmed H. Alfarhan ${ }^{5}$, Yolanda Picó ${ }^{7}$, Damia Barcelo ${ }^{5,8}$

${ }^{1}$ Department of Biology, College of Science, King Khalid University, Abha 61321, P.O. Box 9004, Saudi Arabia

${ }^{2}$ Permanent address: Department of Botany, Faculty of Science, Kafr El-Sheikh University, Kafr El-Sheikh 33516, Egypt

${ }^{3}$ Department of Chemical Engineering, College of Engineering, King Khalid University, Abha 61321, P.O. Box 394, Saudi Arabia

${ }^{4}$ Department of Botany, Faculty of Science, Tanta University, Tanta 31527, Egypt

${ }^{5}$ Botany \& Microbiology Department, College of Science, King Saud University, P.O. Box. 2455, Riyadh 11451, Saudi Arabia

${ }^{6}$ Department of Botany, Faculty of Science, Damanhour University, Damanhour, Egypt

${ }^{7}$ Environmental and Food Safety Research Group of the University of Valencia (SAMA-UV), Desertification Research Centre CIDE (CSIC-UV-GV), Moncada-Naquera Road km 4.5, 46113 Mondada, Valencia, Spain

${ }^{8}$ Water and Soil Research Group, Department of Environmental Chemistry, IDAEA-CSIC, JORDI GIRONA 18-26, 08034 Barcelona, Spain

*Corresponding author: 


\begin{abstract}
The conservation of coastal ecosystems and specially mangroves "blue carbon'" is receiving more attention because of their recognition as high ecosystem carbon stocks and for the fact that these areas are undergoing land conversion. The aim of the present study was to evaluate the impact of land use changes due to conversion of mangroves to shrimp farms on the sediment bulk density (SBD), sediment organic carbon (SOC) concentration, and SOC stock in the sediments along the southern Saudi Arabian Red Sea coast. Shrimp farms and mangrove locations showed significant $(t$-value $=9.3, P<0.001) \mathrm{SBD}$ differences with higher mean values in the sediments of shrimp farms. Shrimp farms and mangrove locations showed significant $(t$-value $=11.1, P<0.001)$ SOC concentration differences with higher mean values in the sediments of mangroves. Considering the whole depth of sediment interval $(0-100 \mathrm{~cm})$, the highest value of SOC stock was recorded at mangroves $\left(29.2 \mathrm{~kg} \mathrm{C} \mathrm{m}^{-2}\right.$ ) and the lowest SOC stock was recorded at the locations of shrimp farms $\left(19.9 \mathrm{~kg} \mathrm{C} \mathrm{m}^{-2}\right)$. The results show that SOC stock of mangroves is $147 \%$ higher than that of shrimp farms confirming the fact that anthropogenic factors contributed significantly to SOC stock value. The mean cumulative potential $\mathrm{CO}_{2}$ emission due to loss soil carbon stock from mangrove conversion to the shrimp ponds was $34.9 \mathrm{~kg} \mathrm{CO}_{2} \mathrm{~m}^{-2}$. In conclusion, the conversion of mangroves into shrimp farms contributed to the loss of SOC stock, therefore, the preservation of mangrove areas has an important value especially in arid areas such as Saudi Arabia.
\end{abstract}

Key words: Blue carbon, Carbon sequestration, Coastal wetlands, Land use change, Red Sea, Shrimp aquacultures. 


\section{Introduction}

Mangrove forest is one of the world's richest ecosystems that supplies a number of ecosystem services contributing to human wellbeing (Atwood et al., 2017; Bao et al., 2013; Eid and Shaltout, 2016). Of these multiple services, which can be grouped into provisioning, habitat and cultural (Abuodha and Kairo, 2001), one of the most important (considering the progress of the global change effects) is their action as carbon sinks (Andreetta et al., 2016; Chen et al., 2018; Ragavan et al., 2019; Sanderman et al., 2018). Mangroves are capable of absorbing and storing carbon from the atmosphere, which ends up buried in the sediments of coastal areas, named as "blue carbon". However, these ecosystems are threatened by pollution, deforestation, fragmentation, rising sea levels and, most importantly, by their transformation for other land uses. These other uses are mainly for aquaculture ponds, but also for urbanization, agriculture or infrastructures development (Arshad et al., 2018; Atwood et al., 2017; Grellier et al., 2017). This environmental problem has a clear global dimension being described by the mangrove disappearance or their transformation to other types of uses in America (Kauffman et al., 2018; Kauffman et al., 2016; Lovelock et al., 2011; Meyer et al., 2019), Asia (Grellier et al., 2017; Kusumaningtyas et al., 2019; Nehren and Wicaksono, 2018; Perera and Amarasinghe, 2019; Vaiphasa et al., 2007; Xin et al., 2014), Africa (Abuodha and Kairo, 2001; Andreetta et al., 2016) and New Zealand (Pérez et al., 2017). To give an idea of the problem, recently the United Nations Environmental Program (UNEP, 2014) reported that one fifth (around 35,500 $\mathrm{km}^{2}$ ) of the world's mangroves have been lost since 1980, with shrimp aquaculture accounting for roughly $38 \%$ of this loss. This mangrove deforestation generates approximately $0.12 \mathrm{Gt}$ of $\mathrm{CO}_{2}$ emissions annually, approximately $0.3 \%$ of total anthropogenic $\mathrm{CO}_{2}$ emissions, becoming an important adverse effect that accentuate global change.

On the contrary, some places are experiencing an increase in the extent of mangrove cover.

In Saudi Arabia, the total coverage of Red Sea's mangrove forests in 1972, 2000 and 2013 was 120, 132 and $135 \mathrm{~km}^{2}$, respectively (Almahasheer et al., 2017). The mangroves of Saudi Arabian Read Sea coast have special characteristics as they growth in the most unfavorable conditions (high salinity values, rivers non-existent, rainfall minimum, hard bottom and very oligotrophic sea). Many studies were carried out on mangrove forests in Saudi Arabia focusing on bioaccumulation (Usman et al., 2013), biomass production (Abohassan, 2013b), distribution of soil organic carbon 
(Almahasheer et al., 2017; Eid et al., 2016), ecology (Almahasheer et al., 2016b), geographical distribution (Khan, 2010; Kumar, 2010), growth dynamics (Almahasheer et al., 2016a), phenology (Almahasheer et al., 2016c), plantation (Elsebaie, 2013; Monsef et al., 2013), pollution (Abohassan, 2013a; Al-Ghanem, 2010; Arshad et al., 2018), population demography (Elhag et al., 2015), restoration (El-Juhany, 2009), sediment composition and stability (Almahasheer et al., 2016a).

In the last years, the economic growth in Saudi Arabia have favored an increase in the carbon emissions in the country (Alkhathlan and Javid, 2015). Mangrove ecosystems offer an unlimited potential to support blue carbon strategies to mitigate these $\mathrm{CO}_{2}$ emissions. Furthermore, Saudi Arabia is not exempt from changes in land use that threaten these ecosystems, and it has been described how coastal development, logging, camel grazing and, particularly, the implementation of shrimp farms led to the loss of mangrove forests (Almahasheer et al., 2016b; Khan, 2010). This study focuses on the latter because their economic incomes in developing countries have brought more attention to this activity. However, to our knowledge, no study has been carried out in Saudi Arabia to evaluate the effect of the conversion of mangroves into shrimp farms on sediment bulk density (SBD), sediment organic carbon (SOC) concentration, and SOC stock. Hence, the aim of this study was to evaluate the impact of land use changes due to conversion of mangroves to shrimp farms on the SOC stocks in the soils along this area. To this end, several partial objectives were established: (1) to assess the vertical distribution of SBD, and SOC concentration in three mangrove locations in comparison with three shrimp farm locations along the southern Red Sea coast of Saudi Arabia; (2) to estimate SOC stock of these locations and (3) to establish potential $\mathrm{CO}_{2}$ emissions arising from mangrove conversion to shrimp ponds. The results of this study are worldwide relevant because could be extrapolated to similar highvalue ecosystems to mitigate carbon emissions in other parts of the planet and serve to mitigate their degradation, as these ecosystems are kept in fragile equilibrium with changing climatic conditions.

\section{Materials and methods}

\subsection{Study area}


The Red Sea stretches out between $30^{\circ} \mathrm{N}$ at the northern end of the Suez Gulf and about $13^{\circ} \mathrm{N}$ at its southern end at Bab El-Mandeb (Fig. 1). The Red Sea coast of Saudi Arabia extends in NW-SE way to a range of $1,700 \mathrm{~km}$, comprising around $80 \%$ of the total length of the sea. Mangroves cover an area around $135 \mathrm{~km}^{2}$ of the Red Sea coastline (Almahasheer et al., 2016a). Mangroves are recognized as fragmented stands in the intertidal zones along the Red Sea coast of Saudi Arabia (Khan, 2010). The stands are dominated by Avicennia marina (El-Juhany, 2009), and are characterized by peak flowering and propagule development in November and January (Almahasheer et al., 2016c). The distribution of mangroves is patchy in this region, and mangrove growth rates are generally low compared to the deltaic zones and estuaries. Previous studies have reported that mangrove forests along the Red Sea coast do not grow in optimal conditions, fundamentally due to high salinity $\left(>40 \mathrm{~g} \mathrm{~L}^{-1}\right)$, hot summer air temperature $\left(37.5-42.0{ }^{\circ} \mathrm{C}\right)$, low rainfall (2.8 - $\left.22.3 \mathrm{~mm} \mathrm{yr}^{-1}\right)$, sandy sediment, low sediment fertility due to low nutrient supply and no permanent freshwater inputs (Almahasheer et al., 2017).

\subsection{Sediment sampling}

Sampling was carried out during December 2017 in three locations $\left(17^{\circ} 48^{\prime} 28.7^{\prime \prime} \mathrm{N}, 41^{\circ}\right.$ $\left.51^{\prime} 57.0^{\prime \prime} \mathrm{E} ; 17^{\circ} 47^{\prime} 31.5^{\prime \prime} \mathrm{N}, 4^{\circ} 53^{\prime} 18.5^{\prime \prime} \mathrm{E} ; 17^{\circ} 10^{\prime} 43.9^{\prime \prime} \mathrm{N}, 42^{\circ} 22^{\prime} 2.1^{\prime \prime} \mathrm{E}\right)$ to represent the monospecific stands of mangroves (A. marina) and another three locations $\left(17^{\circ} 47^{\prime} 37.5^{\prime \prime} \mathrm{N}, 41^{\circ}\right.$ $53^{\prime} 49.9^{\prime \prime} \mathrm{E} ; 17^{\circ} 46^{\prime} 40.8^{\prime \prime} \mathrm{N}, 4^{\circ} 54^{\prime} 37.3^{\prime \prime} \mathrm{E} ; 17^{\circ} 13^{\prime} 17.0^{\prime \prime} \mathrm{N}, 42^{\circ} 20^{\prime} 20.5^{\prime \prime} \mathrm{E}$ ) to represent the shrimp farms along the Saudi Arabian Red Sea coast (Fig. 1). Six soil cores were collected from the six sites in each sampling location. Samples at both shrimp farms and mangroves locations were collected randomly with the aid of hand sediment corer (made of stainless steel, $75 \mathrm{~cm}$ long with an inner diameter of $70 \mathrm{~mm}$ ). The corer was inserted into the sediment and pushed down to a depth of $100 \mathrm{~cm}$, and the sediment core removed from the corer slowly and immediately sectioned with a blade into $10 \mathrm{~cm}$ thick layers $(0-10,10-20,20-30,30-40,40-50,50-60,60-70,70-80,80$ 90 and 90-100 cm) and packed in plastic containers. Parafilm was used to tighten the sample containers, after which they were stored on ice to prevent volatilization losses and to reduce the microbial activity till analysis (Eid and Shaltout, 2016). In total, 360 sediment samples were collected to determine SBD, SOC concentration, and SOC stock, i.e., one sample from each ten soil layers at each of the 36 sampling sites (18 sampling sites per each of shrimp farms and mangroves locations). 


\subsection{Sample analysis}

Each sediment sample was oven-dried at $105{ }^{\circ} \mathrm{C}$ for three days and weighed to determine the SBD $\left(\mathrm{g} \mathrm{cm}^{-3}\right)$ following the method of (Wilke, 2005). Dry samples were ground and sieved to pass through $2 \mathrm{~mm}$ particle size. Each sample was analyzed for SOC concentration by measuring the sediment organic matter (SOM) using loss-on-ignition method at $550{ }^{\circ} \mathrm{C}$ for two hours as described by (Jones, 2001), where SOC concentration $\left(\mathrm{g} \mathrm{C} \mathrm{kg}^{-1}\right)=0.50($ Pribyl, 2010) $\times \mathrm{SOM}(\mathrm{g}$ $\left.\mathrm{C} \mathrm{kg}^{-1}\right)$. As the authors did not possess a carbon hydrogen and nitrogen ( $\left.\mathrm{CHN}\right)$ analyzer, they relied on loss-on-ignition method being recommended by Nóbrega et al. (2015) for an accurate estimation of SOC in mangrove sediments. SOC stock $\left(\mathrm{kg} \mathrm{C} \mathrm{m}^{-2}\right)$ was calculated as follows (Meersmans et al., 2008):

$$
S O C_{s}=\frac{\sum_{j=1}^{k} p_{s j} \times S O C_{j} \times T_{j}}{\sum_{j=1}^{k} T_{j}} \times D_{r}
$$

where $S O C_{s}$ is $\mathrm{SOC}$ stock $\left(\mathrm{kg} \mathrm{C} \mathrm{m}^{-2}\right), \rho_{s j}$ is the $\operatorname{SBD}\left(\mathrm{g} \mathrm{cm}^{-3}\right)$ of the $j^{\text {th }}$ layer, $S O C_{j}$ is the SOC concentration $\left(\mathrm{g} \mathrm{C} \mathrm{kg}^{-1}\right)$ of the $j^{\text {th }}$ layer, $D_{r}$ is reference depth $(=1 \mathrm{~m}), T_{j}$ is thickness $(\mathrm{m})$ of the $j^{\text {th }}$ layer and $k$ is the number of layers $(=10)$.

The ecosystem losses due to the transformation of mangrove into shrimp farms (only due to the $\mathrm{C}$ stocks stored in sediments) are reported as potential $\mathrm{CO}_{2}$ emissions, or $\mathrm{CO}_{2}$ equivalents $\left(\mathrm{CO}_{2} \mathrm{e}\right)$ obtained by multiplying $\mathrm{C}$ values by 3.67 , the molecular ratio of $\mathrm{CO}_{2}$ to $\mathrm{C}$ (Kauffman et al., 2018).

\subsection{Statistical analysis}

The data were examined for their normality of distribution and homogeneity of variance, and when required, log-transformed before performing analysis of variance (ANOVA). Two-way analysis of variance (ANOVA-2) was used to identify statistically significant differences in SOC concentrations and SBD among mangroves and shrimp farms in each sediment layer. To identify significant difference between means, the Tukey's HSD test at $\mathrm{P}<0.05$, was used. The relationship between SBD and SOC concentration was examined with non-linear regression (Eid and Shaltout, 2016). To identify statistically significant differences in the total means of SBD, SOC concentration, and SOC stock among mangroves and shrimp farms, a student's $t$-test was performed. SPSS 15.0 software (SPSS, 2006) was used to perform all the statistical analyses. 


\section{Results}

With respect to SBD, differences $(t$-value $=9.3, P<0.001)$ were found between shrimp farms and mangroves, with higher mean values in the sediments of shrimp farms (Table 1). There was a noticeable variation in SDB at mangroves showing an increase in from $1.21 \mathrm{~g} \mathrm{~cm}^{-3}$ at a depth of $0-10 \mathrm{~cm}$ to $2.08 \mathrm{~g} \mathrm{~cm}^{-3}$ at a depth of $90-100 \mathrm{~cm}$ (Fig. 2), while the SBD distribution at the shrimp farms varied from $1.28 \mathrm{~g} \mathrm{~cm}^{-3}$ at a depth of $0-10 \mathrm{~cm}$ to $2.43 \mathrm{~g} \mathrm{~cm}^{-3}$ at a depth of $90-$ $100 \mathrm{~cm}$. Mangroves and shrimp farms showed significant $(t$-value $=11.1, P<0.001) \mathrm{SOC}$ concentration differences with higher mean values in the sediments of mangroves (Table 1). SOC concentrations in mangroves have declined from $32.8 \mathrm{~g} \mathrm{C} \mathrm{kg}^{-1}$ at a depth of 0-10 $\mathrm{cm}$ to $6.9 \mathrm{~g} \mathrm{C}$ $\mathrm{kg}^{-1}$ at a depth of 90-100 cm (Fig. 3) and in the shrimp farms from $22.9 \mathrm{~g} \mathrm{C} \mathrm{kg}^{-1}$ at a depth of 0$10 \mathrm{~cm}$ to $4.5 \mathrm{~g} \mathrm{C} \mathrm{kg}^{-1}$ at a depth of 90-100 $\mathrm{cm}$. SOC concentration $\left(\mathrm{g} \mathrm{C} \mathrm{kg}^{-1}\right)$ and $\mathrm{SBD}\left(\mathrm{g} \mathrm{cm}^{-3}\right)$ had a significant and inverse relationship described by the following non-linear regression equations: $\mathrm{SBD}=0.969+1.778 \mathrm{e}^{-0.065 \times \text { SOC concentration }}(r=-0.761, P<0.001)$ and $\mathrm{SBD}=0.705+$ $1.884 \mathrm{e}^{-0.041 \times \text { SOC concentration }}(r=-0.854, P<0.001)$ for the locations of shrimp farms and mangroves, respectively (Fig. 4). Considering the whole depth of sediment interval $(0-100 \mathrm{~cm})$, the highest value of SOC stock was recorded at mangroves $\left(29.2 \mathrm{~kg} \mathrm{C} \mathrm{m}^{-2}\right)$ and the lowest SOC stock was recorded at shrimp farms $\left(19.9 \mathrm{~kg} \mathrm{C} \mathrm{m}^{-2}\right)$. It was observed that the SOC stock of mangroves is $147 \%$ higher than that of shrimp farms confirming the transformation of mangrove areas to shrimp farks contributed significantly to SOC stock value.

\section{Discussion}

The lower SBD of mangroves compared to shrimp farms highlights the positive effect on the sediment of the Red Sea resulting in a lowering of the SBD in comparison to that of the shrimp farms, particularly important at lower depths. This could be attributed to the growth of A. marina, plant species relevant for the reduction of SBD as contribute organic matter and also protect the coastal areas from erosion processes. Both roots and litter, and the consequent activity of wild aquatic biota, result in an increase in pore and macropore development. This agree with most of the studies that compared the SBD of preserved mangrove areas to other that have changed the land cover (Arifanti et al., 2019; Atwood et al., 2017; Cameron et al., 2019; Perera and 
Amarasinghe, 2019). The SBD values found in Saudi Arabia are slightly higher than those reported in similar ecosystems of Indonesia and New Zealand but similar to those of Sri Lanka. This is clearly related with the sediment variability among different areas and at different depths and could indicated just different characteristics.

Significant increases in SBD with depth was observed in the shrimp farm and mangroves $(F$-value $=164.2, P<0.001)$. This has been reported in many other studies carried out not only in mangroves but also in a variety of ecosystems (Arifanti et al., 2019; Atwood et al., 2017; Cameron et al., 2019; El-Sheikh et al., 2018; Perera and Amarasinghe, 2019). The main differences between the SBD of mangroves and shrimp farms sediments were observed at depths between 0 and $20 \mathrm{~cm}$ and more markedly at depths greater than $40 \mathrm{~cm}$. On the contrary, at depths of 20 to $40 \mathrm{~cm}$, the sediment SBD did not show any significant difference between mangroves and shrimp farms. The progressive decrease with depth (up to $50 \mathrm{~cm}$ ) of the differences in SBD between mangrove areas and shrimp farms has been described by Grellier et al. (2017). However, these authors did not study greater depths and therefore it is not possible to establish whether the behaviour described is fully in line with that found in the Red Sea. Contrarily, Arifanti et al. (2019) who perform the study up to $3 \mathrm{~m}$ depth only reflect a progressive increase SBD with depth. One potential explanation to this behaviour that needs further confirmation is that sediments in mangrove areas are more affected by sediment dynamics than shrimp ponds. These areas are a buffer between the sea and the land. They actively accumulate sediments from the tidal creeks and coastal oceans. Contrarily, the shrimp pools are static and the water inlet and outlet are regulated by the human being.

The SOC content provide novel insights on its distribution in the mangrove and shrimp farm land in the Red Sea Coast of Saudi Arabia. The mangrove sites of Red Sea showed higher SOC content than their adjacent shrimp farms that partly reflect the differences in SBD previously discussed. The SOC content decrease due to conversion of mangrove to shrimp farm could be observed along the whole sediment profile (see Fig. 3). SOC in mangrove areas is likely a result of A. marina, mainly due to litter fall and underground roots instead, in the shrimp farm, the vegetal cover has been eliminated. Other studies on the variation of SOC content in mangrove areas due to changes in land use coincide with the present finding by always indicating a significant decrease in SOC content in the transformed areas (Andreetta et al., 2016; Arifanti et al., 2019; Bhomia et 
al., 2016; Cameron et al., 2019; Gevana et al., 2015; Kauffman et al., 2018; Kauffman et al., 2016; Pérez et al., 2017). The decline in the amount of organic matter in the shrimp farms has been attributed to decomposition of the organic matter in soils especially during periods when the ponds were drained after shrimp harvests. Draining and limiting tidal flows likely created aerobic conditions favorable for carbon oxidation (Arifanti et al., 2019).

A general trend observed with respect to SOC contents in sediments of tropical forests including mangroves was decreasing SOC with increasing depth. A similar trend was observed in both, mangrove area and shrimp farm. Our results are in accordance with numerous studies (e.g., Arifanti et al., 2019; Eid and Shaltout, 2016; Eid et al., 2016; Gevana et al., 2015; Khan et al., 2018; Kauffman et al., 2018; Perera and Amarasinghe, 2019), which documented the high capacity for organic carbon sequestration of Mangrove soils in comparison to that reported when these mangroves are transformed to other land used. The SOC depth profile for both study sites also reflects the differences in the SBD. Negative correlations between SBD and SOC content were easily explainable as organic matter increases the porosity. Differences in SOC content between mangroves and shrimp farms decrease from surface to depths of $20-40 \mathrm{~cm}$ to become more pronounced at greater depths. SOC content in Saudi Arabia mangrove areas (32.8-6.2 $\mathrm{g} \mathrm{C} \mathrm{kg}^{-1}$ ) is in line with other study in Egypt (other side of Red Sea) (20.0-11. $4 \mathrm{~g} \mathrm{C} \mathrm{kg}^{-1}$ ) (Eid and Shaltout, 2016).

The comparison of mean soil C stocks in the $1 \mathrm{~m}$ between mangroves $\left(29.2 \pm 0.4 \mathrm{~kg} \mathrm{C} \mathrm{m}^{-2}\right)$ and shrimp farms $\left(19.9 \pm 0.8 \mathrm{~kg} \mathrm{C} \mathrm{m}^{-2}\right)$ resulted in soil loss of $9.3 \mathrm{~kg} \mathrm{C} \mathrm{m}^{-2}$. These SOC stocks are higher than those previously reported by (Atwood et al., 2017) (72 $\mathrm{Mg} \mathrm{C} \mathrm{h}^{-1} \equiv 7.2 \mathrm{~kg} \mathrm{C} \mathrm{m}^{-2}$ ) and for Serrano et al. (2018) (4.5 $\left.\mathrm{kg} \mathrm{C} \mathrm{m}^{-2}\right)$ for mangroves of Saudi Arabia. Results of our study triplicate the SOC stocks in mangrove area and duplicate them in shrimp farms. These discrepancies can be due to the scarce number of existing data and the variability of the own ecosystems across the Red Sea since Atwood et al. (2017) already mention that the data represent less than $30 \%$ of Saudi Arabia marine eco-regions with mangroves.

Comparing with the other studies worldwide, SOC stocks in Saudi Arabia mangrove areas (29.2 $\mathrm{kg} \mathrm{C} \mathrm{m}^{-2}$ ) was lower than that of the mangrove forests in Sri Lanka (59.0) (Perera and Amarasinghe, 2019), Indonesia (68.8 $\mathrm{kg} \mathrm{C} \mathrm{m}^{-2}$ ) (Kusumaningtyas et al., 2019), Brazil (41.8 kg C $\mathrm{m}^{-2}$ ) (Kauffman et al., 2018), Dominican Republic (70.8-113.1) (Kauffman et al., 2014) and 
Micronesia (Kauffman et al., 2011). On the other hand, SOC stocks in the studied area were higher than the reported values in Egypt (8.5 $\mathrm{kg} \mathrm{C} \mathrm{m}^{-2}$ ) (Eid and Shaltout, 2016), Vietnam $\left(5.8 \mathrm{~kg} \mathrm{C} \mathrm{m}^{-2}\right.$ ) (Grellier et al., 2017) and New Zealand $\left(6.9 \mathrm{~kg} \mathrm{C} \mathrm{m}^{-2}\right.$ ) (Pérez et al., 2017). The results obtained in our study are not totally discrepant with the previous ones that included this area (Almahasheer et al., 2017; Atwood et al., 2017). However, the low capacity to act as carbon sinks that has been attributed to the mangroves of this area may not really be as low and that its importance in mitigating the effects of global change may be greater than that traditionally attributed to it. Shrimp farms present a decline in the carbon stocks compared to adjacent mangroves of $31.8 \%$. Soils were the almost only carbon pool for shrimp farms where the vegetative cover overlaying ponds has disappear (Fig.1) and carbon stock was limited to that contained in soil. That means that the decline of carbon stocks are higher than those due only to the loss of soil carbon stocks.

The mean cumulative potential $\mathrm{CO}_{2}$ emission due to soil carbon stock from mangrove conversion to the shrimp ponds was $34.9 \mathrm{~kg} \mathrm{CO}_{2} \mathrm{~m}^{-2}$. Kauffman et al. (2018) reported the mean potential carbon emission associated with mangrove conversion to shrimp ponds was $139 \mathrm{~kg} \mathrm{CO}_{2} \mathrm{e}$ $\mathrm{m}^{-2}$ in Brazil that is higher than that reported in our study. Similarly carbon losses from soils at depths $>100 \mathrm{~cm}$ were found in Mexican cattle pastures converted from mangroves $(143 \mathrm{~kg} \mathrm{CO}$ $\mathrm{m}^{-2}$ ) (Kauffman et al., 2016) as well as in shrimp ponds in Indonesia $\left(226 \mathrm{Kg} \mathrm{CO}_{2} \mathrm{~m}^{-2}\right.$ ) (Arifanti et al., 2019). The significant losses of carbon from the shrimp ponds reported here are likely underestimates because the carbon accumulate in the mangrove areas as biomass have not been taken into account and this land use affects carbon dynamics outside of the boundaries of the shrimp ponds. Another aspect less taken into account is the effects that the discharges from the shrimp farms may have on the neighboring mangroves. Vaiphasa et al. (2007) reported that shrimp pond effluents had dramatic effects on the survival of mangroves surrounding ponds. Given the importance of these ecosystems as carbon sinks, these aspects must be taken into account much more than they have been so far.

\section{Conclusions}

The SOC content and density profile and SBD distribution in mangroves and shrimp farms have shown that mangroves have lower SBD and more organic matter than fish farms. The organic matter contents in the $0-10 \mathrm{~cm}$ sediment depth accounts for $34.9 \%$ of total SOC content in the 
studied sediments, which indicates that the mangrove layer can be carbon sink. This study demonstrated how mangroves improve the SOC content of the sediments. One of the ecosystem services provided by mangrove areas is the increased efficiency of soil carbon sequestration because mangrove trees are appropriate organic matter sources. This study is an example of how the transformation of mangroves by anthropogenic pressure in some areas, can degrade sediments organic matter storm and pinpointed the importance of preservation and afforestation projects that will help to increase the mangrove areas. The preservations of these areas, instead of their transformation in aquaculture ponds can help to fight against climate change and reduce the effect of the anthropogenic pressure.

\section{Acknowledgements}

The financial support from the Distinguished Scientist Fellowship Program (DSFP) from King Saud University, Saudi Arabia is gratefully acknowledged.

\section{References}

Abohassan, R. A. A. O., C.A.; Agea, J.G.; Kimondo, J.M.; McDonald, M.M., 2013b. Perennial biomass production in arid mangrove systems on the Red Sea coast of Saudi Arabia. Environmental Research Journal. 6, 9.

Abohassan, R. A. A., 2013a. Heavy metal pollution in Avicennia marina mangrove systems on the Red Sea coast of Saudi Arabia. Journal of King Abdulaziz University: Meteorology, Environment \& Arid Land Agriculture Sciences 24, 18.

Abuodha, P. A. W., Kairo, J. G., 2001. Human-induced stresses on mangrove swamps along the Kenyan coast. Hydrobiologia. 458, 255-265.

Al-Ghanem, W. M., 2010. Ecological study of Avicenia marina in Saudi Arabia, Al-Qatif District east Saudi Arabia. Journal of the Arabian Acuaculture Society. 5, 9.

Alkhathlan, K., Javid, M., 2015. Carbon emissions and oil consumption in Saudi Arabia. Renewable and Sustainable Energy Reviews. 48, 105-111.

Almahasheer, H., et al., 2016a. Decadal stability of Red Sea mangroves. Estuarine, Coastal and Shelf Science. 169, 164-172.

Almahasheer, H., et al., 2016b. Nutrient limitation in central Red Sea mangroves. Frontiers in Marine Science. 3. 
Almahasheer, H., et al., 2016c. Phenology and Growth dynamics of Avicennia marina in the central Red Sea. Scientific Reports. 6, 37785.

Almahasheer, H., et al., 2017. Low Carbon sink capacity of Red Sea mangroves. Scientific reports. 7, 9700 .

Andreetta, A., et al., 2016. Land use changes affecting soil organic carbon storage along a mangrove swamp rice chronosequence in the Cacheu and Oio regions (northern GuineaBissau). Agriculture, Ecosystems and Environment. 216, 314-321.

Arifanti, V. B., et al., 2019. Carbon dynamics and land use carbon footprints in mangroveconverted aquaculture: The case of the Mahakam Delta, Indonesia. Forest Ecology and Management. 432, 17-29.

Arshad, M., Alrumman, S. A., Eid, E. M., 2018. Evaluation of carbon sequestration in the sediment of polluted and non-polluted locations of mangroves. Fundamental \& Applied Limnology. 192, 53-64.

Atwood, T. B., et al., 2017. Global patterns in mangrove soil carbon stocks and losses. Nature Climate Change. 7, 523-528.

Bao, H., et al., 2013. Impact of the conversion of mangroves into aquaculture ponds on the sedimentary organic matter composition in a tidal flat estuary (Hainan Island, China). Continental Shelf Research. 57, 82-91.

Bhomia, R. K., et al., 2016. Impacts of land use on Indian mangrove forest carbon stocks: Implications for conservation and management. Ecological Applications. 26, 1396-1408.

Cameron, C., et al., 2019. Community structure dynamics and carbon stock change of rehabilitated mangrove forests in Sulawesi, Indonesia. Ecological Applications. 29.

Chen, S., et al., 2018. Ecosystem carbon stock of a tropical mangrove forest in North Sulawesi, Indonesia. Acta Oceanologica Sinica. 37, 85-91.

Eid, E. M., El-Bebany, A. F., Alrumman, S. A., 2016. Distribution of soil organic carbon in the mangrove forests along the southern Saudi Arabian Red Sea coast. Rendiconti Fisiche Accademia Lincei. 27, 629-637.

Eid, E. M., Shaltout, K. H., 2016. Distribution of soil organic carbon in the mangrove Avicennia marina (Forssk.) Vierh. along the Egyptian Red Sea Coast. Regional Studies in Marine Science. 3, 76-82.

Elhag, M., et al., 2015. Population demography and global sensitivity analysis of Avicennia marina on the eastern and western coasts of Saudi Arabia. Koedoe. 57, a1317. 
El-Juhany, L. I., 2009. Present status and degradation trends of mangrove forests on the southern Red Sea coast of Saudi Arabia. American-Eurasian Journal of Agricultural and Environmental Science. 6, 12.

Elsebaie, I. H. A., A.S.H.; Al Garni, D., 2013. The role of remote sensing and GIS for locating suitable mangrove plantation sites along the southern Saudi Arabian Red Sea coast. International Journal of Geoscience. 4, 8.

El-Sheikh, M. A., et al., 2018. Distribution of soil organic carbon in Wadi Al-Thulaima, Saudi Arabia: A hyper-arid habitat altered by wastewater reuse. CATENA. 170, 266-271.

Gevana, D., et al., 2015. Land use characterization and change detection of a small mangrove area in Banacon Island, Bohol, Philippines using a maximum likelihood classification method. Forest Science and Technology. 11, 197-205.

Grellier, S., et al., 2017. Changes in soil characteristics and C dynamics after mangrove clearing (Vietnam). Science of the Total Environment. 593-594, 654-663.

Jones, J., 2001. Laboratory Guide for Conducting Soil Tests and Plant Analysis. CRC Press, Boca Raton.

Kauffman, J. B., et al., 2014. Carbon stocks of intact mangroves and carbon emissions arising from their conversion in the Dominican Republic. Ecological Applications. 24, 518-527.

Kauffman, J. B., et al., 2016. Carbon stocks of mangroves and losses arising from their conversion to cattle pastures in the Pantanos de Centla, Mexico. Wetlands Ecology and Management. 24, 203-216.

Kauffman, J. B., et al., 2018. Shrimp ponds lead to massive loss of soil carbon and greenhouse gas emissions in northeastern Brazilian mangroves. Ecology and Evolution. 8, 5530-5540.

Khan, M. A. K., A.; Muqtadir, A., 2010. Distribution of mangroves along the Red Sea coast of the Arabian Peninsula: Part 2. The southern coast of western Saudi Arabia. Earth Science India 3,8 .

Kumar, A. K., M.A.; Muqtadir, A., 2010. Distribution of mangroves along the Red Sea coast of the Arabian Peninsula: Part 1. The northern coast of western Saudi Arabia. Earth Science India. 3, 14.

Kusumaningtyas, M. A., et al., 2019. Variability in the organic carbon stocks, sources, and accumulation rates of Indonesian mangrove ecosystems. Estuarine, Coastal and Shelf Science. 218, 310-323.

Lovelock, C. E., et al., 2011. Co2 efflux from cleared mangrove peat. PLoS ONE. 6. 
Meersmans, J., et al., 2008. A multiple regression approach to assess the spatial distribution of Soil Organic Carbon (SOC) at the regional scale (Flanders, Belgium). Geoderma. 143, 1-13.

Meyer, V., et al., 2019. Forest degradation and biomass loss along the Chocó region of Colombia. Carbon Balance and Management. 14.

Monsef, H. A.-E., et al., 2013. Locating suitable mangrove plantation sites along the Saudi Arabia Red Sea Coast. Journal of African Earth Sciences. 83, 1-9.

Nehren, U., Wicaksono, P., 2018. Mapping soil carbon stocks in an oceanic mangrove ecosystem in Karimunjawa Islands, Indonesia. Estuarine, Coastal and Shelf Science. 214, 185-193.

Nóbrega, G. N., et al., 2015. Evaluation of methods for quantifying organic carbon in mangrove soils from semi-arid region. Journal of Soils and Sediments. 15, 282-291.

Perera, K. A. R. S., Amarasinghe, M. D., 2019. Carbon sequestration capacity of mangrove soils in micro tidal estuaries and lagoons: A case study from Sri Lanka. Geoderma. 347, 80-89.

Pérez, A., et al., 2017. Changes in organic carbon accumulation driven by mangrove expansion and deforestation in a New Zealand estuary. Estuarine, Coastal and Shelf Science. 192, 108116.

Pribyl, D. W., 2010. A critical review of the conventional SOC to SOM conversion factor. Geoderma. 156, 75-83.

Ragavan, P., et al., 2019. Carbon storage potential of mangroves - are we missing the boat? Current Science. 116, 889-891.

Sanderman, J., et al., 2018. A global map of mangrove forest soil carbon at $30 \mathrm{~m}$ spatial resolution. Environmental Research Letters. 13, 055002.

Serrano, O., et al., 2018. Carbon stocks and accumulation rates in Red Sea seagrass meadows. Scientific Reports. 8.

SPSS, SPSS Base 15.0 User’s Guide. 2006.

UNEP, Destruction of Carbon-Rich Mangroves Costs up to US\$42 billion in Economic Damages Annually - UNEP Report. 2014.

Usman, A. R. A., et al., 2013. Heavy metal contamination in sediments and mangroves from the coast of Red Sea: Avicennia marina as potential metal bioaccumulator. Ecotoxicology and Environmental Safety. 97, 263-270.

Vaiphasa, C., et al., 2007. Impact of solid shrimp pond waste materials on mangrove growth and mortality: A case study from Pak Phanang, Thailand. Hydrobiologia. 591, 47-57.

Page 14 of 21 
Wilke, B. M., Determination of chemical and physical soil properties. In: R. Margesin, F. Schinner, (Eds.), Monitoring and Assessing Soil Bioremediation. Springer Berlin Heidelberg, Berlin, Heidelberg, 2005, pp. 47-95.

Xin, K., et al., 2014. Land use change impacts on heavy metal sedimentation in mangrove wetlands - A case study in Dongzhai Harbor of Hainan, China. Wetlands. 34, 1-8. 


\section{Table 1}

Mean \pm standard error of sediment bulk density $\left(\mathrm{SBD} ; \mathrm{g} \mathrm{cm}^{-3}\right)$, sediment organic carbon (SOC) concentration $\left(\mathrm{g} \mathrm{C} \mathrm{kg}^{-1}\right)$ and SOC stock $\left(\mathrm{kg} \mathrm{C} \mathrm{m}^{-2}\right)$ in the locations of shrimp farms and mangroves (Avicennia marina) along the southern Red Sea coast of Saudi Arabia. $t$-values represent the student's $t$-test. ***: $P<0.001$.

\begin{tabular}{llll}
\hline Location & SBD $\left(\mathrm{g} \mathrm{cm}^{-3}\right)$ & SOC concentration $\left(\mathrm{g} \mathrm{C} \mathrm{kg}^{-1}\right)$ & SOC stock $\left(\mathrm{kg} \mathrm{C} \mathrm{m}^{-2}\right)$ \\
\hline Shrimp farms & $1.82 \pm 0.03(n=180)$ & $12.9 \pm 0.6(n=180)$ & $19.9 \pm 0.8(n=18)$ \\
Mangroves & $1.66 \pm 0.02(n=180)$ & $17.7 \pm 0.6(n=180)$ & $29.2 \pm 0.4(n=18)$ \\
$t$-value & $9.3^{* * *}$ & $11.1^{* * *}$ & $9.5 * * *$ \\
\hline
\end{tabular}




\section{Figures captions}

Fig. 1. Map of the study area indicating the six sampling locations.

Fig. 2. Distribution of sediment bulk density $\left(\mathrm{g} \mathrm{cm}^{-3}\right)$ in relation to sediment depth $(\mathrm{cm})$ in the locations of shrimp farms and mangroves (Avicennia marina) along the southern Red Sea coast of Saudi Arabia. Horizontal bars indicate the standard errors of the means $(n=18) . F$-values represent the two-way ANOVAs. Location: shrimp farms/mangroves; Depth: 0-10, 10-20, 20-30, 30-40, 4050, 50-60, 60-70, 70-80, 80-90, 90-100 cm. ***: $P<0.001$. Means followed by different letters are significantly different at $P<0.05$ according to the Tukey's HSD test.

Fig. 3. Distribution of sediment organic carbon concentration $\left(\mathrm{g} \mathrm{C} \mathrm{kg}^{-1}\right)$ in relation to sediment depth $(\mathrm{cm})$ in the locations of shrimp farms and mangroves (Avicennia marina) along the southern Red Sea coast of Saudi Arabia. Horizontal bars indicate the standard errors of the means $(n=18)$. $F$-values represent the two-way ANOVAs. Location: shrimp farms/mangroves; Depth: 0-10, 1020, 20-30, 30-40, 40-50, 50-60, 60-70, 70-80, 80-90, 90-100 cm. **: $P<0.01, * * *: P<0.001$. Means followed by different letters are significantly different at $P<0.05$ according to the Tukey's HSD test.

Fig. 4. Non-linear correlation between sediment organic carbon concentration $\left(\mathrm{g} \mathrm{C} \mathrm{kg}^{-1}\right)$ and sediment bulk density $\left(\mathrm{g} \mathrm{cm}^{-3}\right)$ of 360 sediment samples from the locations of shrimp farms and mangroves (Avicennia marina) along the southern Red Sea coast of Saudi Arabia. 




Fig.1. 


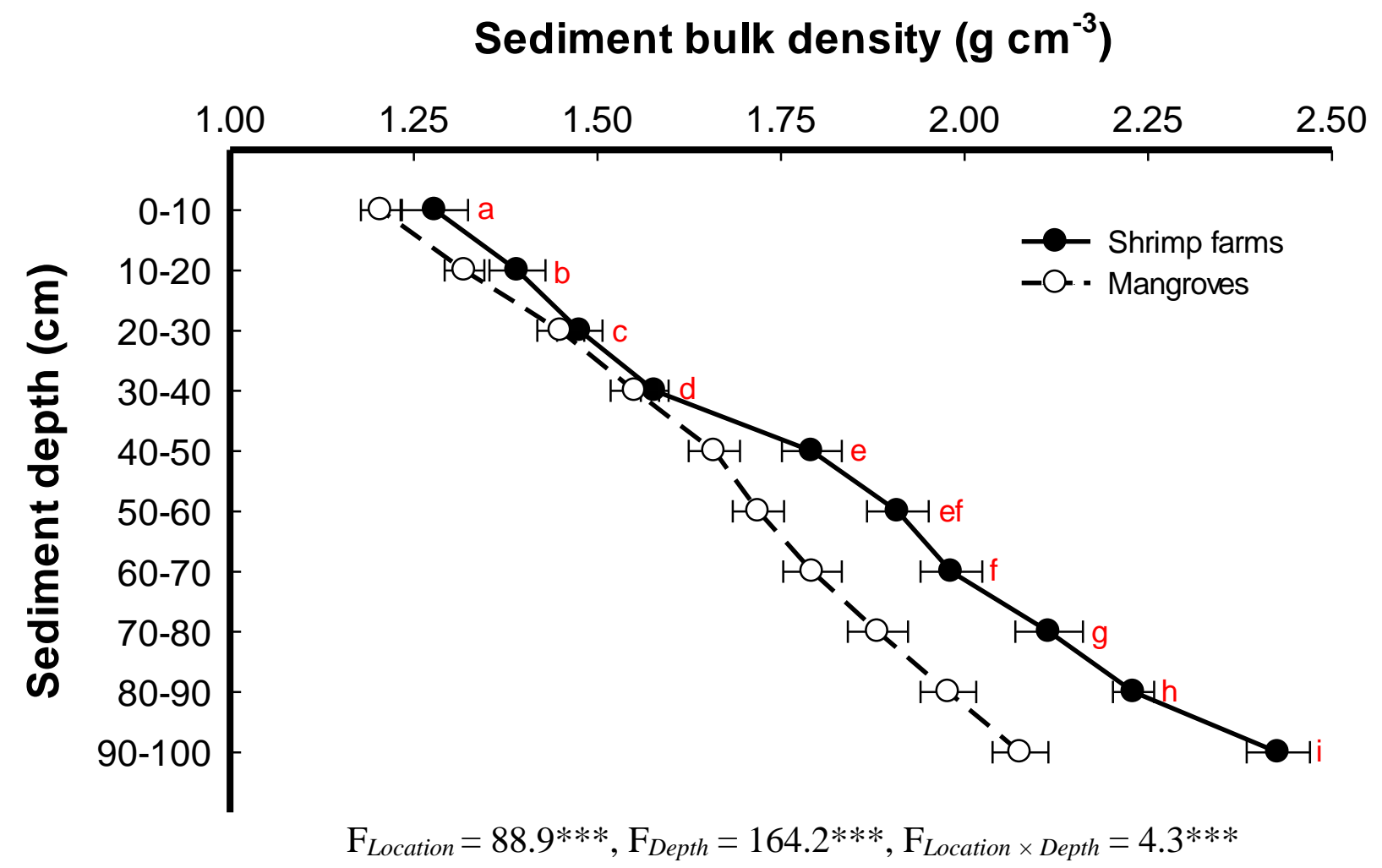

Fig.2. 


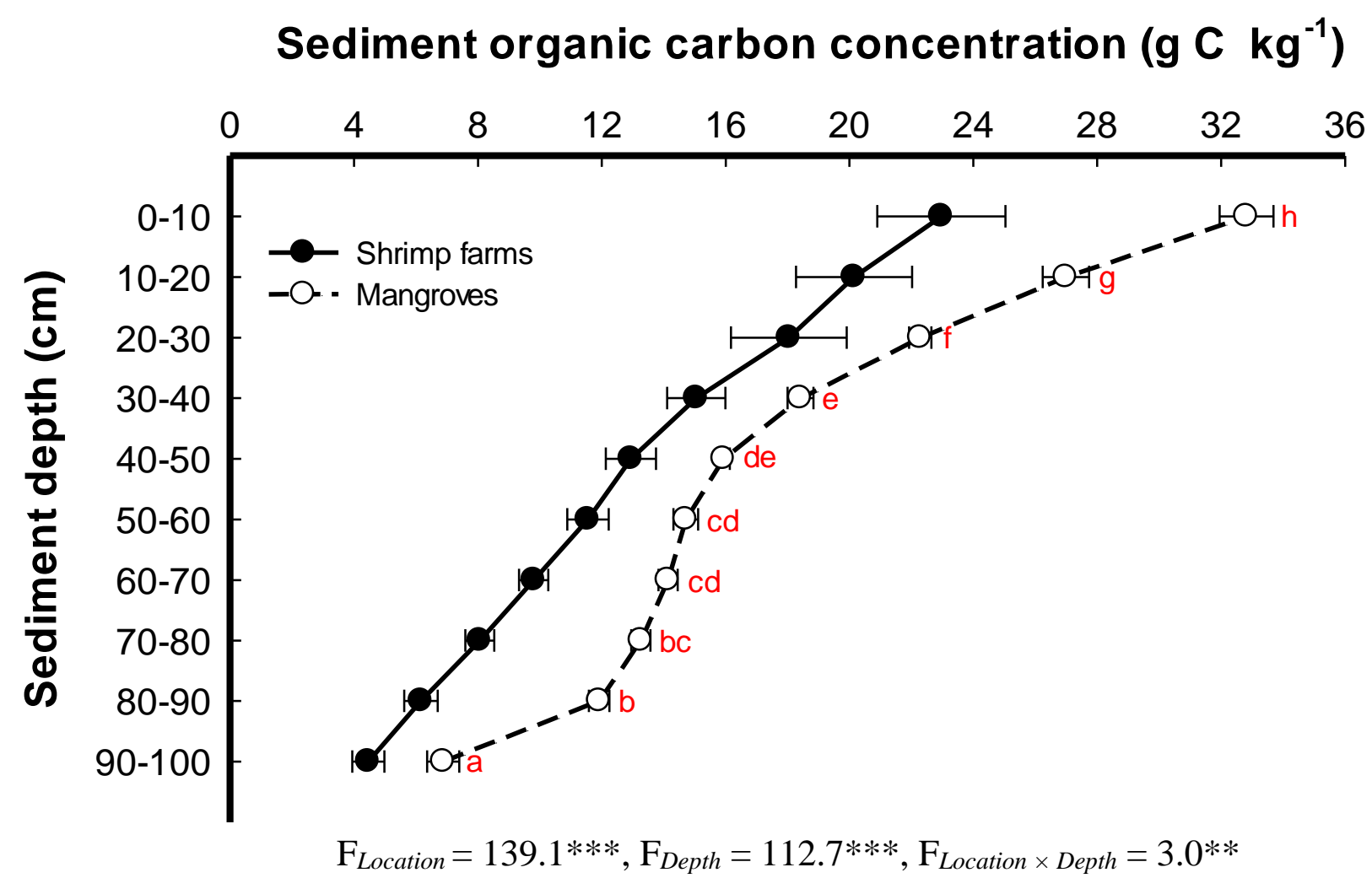

Fig.3 


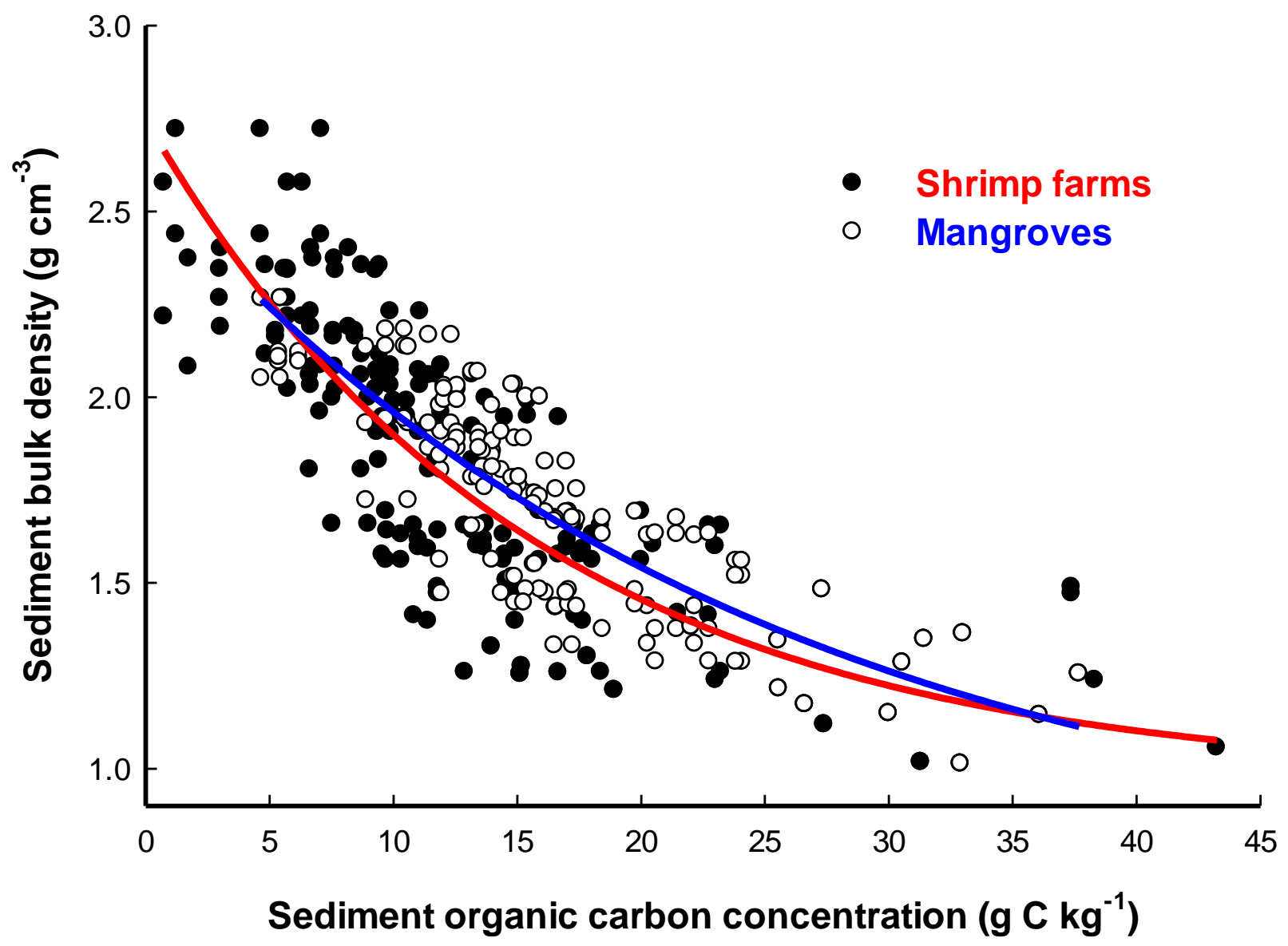

Fig.4 